\title{
Article \\ The Problem of Determining Discount Rate for Integrated Investment Projects in the Oil and Gas Industry
}

\author{
Alexey Komzolov ${ }^{1, \dagger}$, Tatiana Kirichenko ${ }^{1, \dagger}$, Olga Kirichenko ${ }^{2,+}$, Yulia Nazarova ${ }^{1,+}$ (b) \\ and Natalya Shcherbakova $3, *,+$ \\ 1 Department of Security of Digital Economy and Risk Management, National University of Oil and Gas \\ «Gubkin University», 65 Leninsky Prospekt, 119991 Moscow, Russia; komzolov.a@gubkin.ru (A.K.); \\ kirichenko.t@gubkin.ru (T.K.); nazarova-yua@rudn.ru (Y.N.) \\ 2 The Department of Sectoral Markets, Financial University under the Government of the Russian Federation, \\ 49/2 Leningradsky Prospekt, 125167 Moscow, Russia; OSKirichenko@fa.ru \\ 3 Faculty of Economics, Peoples' Friendship University of Russia (RUDN University), 6 Miklukho-Maklaya \\ Street, 117198 Moscow, Russia \\ * Correspondence: shcherbakova-ns@rudn.ru \\ + These authors contributed equally to this work.
}

check for updates

Citation: Komzolov, A.; Kirichenko, T.; Kirichenko, O.; Nazarova, Y.; Shcherbakova, N. The Problem of Determining Discount Rate for Integrated Investment Projects in the Oil and Gas Industry. Mathematics 2021, 9, 3327. https://doi.org/ $10.3390 /$ math 9243327

Academic Editors: Anna Firsova and Galina Chernyshova

Received: 28 November 2021 Accepted: 17 December 2021 Published: 20 December 2021

Publisher's Note: MDPI stays neutral with regard to jurisdictional claims in published maps and institutional affiliations.

Copyright: (c) 2021 by the authors. Licensee MDPI, Basel, Switzerland. This article is an open access article distributed under the terms and conditions of the Creative Commons Attribution (CC BY) license (https:// creativecommons.org/licenses/by/ $4.0 /)$.

\begin{abstract}
The main aim of this paper was to examine specific approaches to determining the discount rate for comprehensive computation of investment projects efficiency in the oil and gas industry. The objective of the study was to develop a scientific approach for determining the discount rate for integrated oil and gas projects. The authors analyze dynamic methods for determining the efficiency of investment projects in the oil and gas industry and conclude that they are advisable for oil and gas projects due to the high capital intensity of the projects and their long payback period. Regarding the need to implement dynamic indicators of efficiency, the authors set the task of deter-mining the proper discount rate as a factor having a significant impact on effectiveness evaluation. The discount rate is proposed to be evaluated by solving the equation and finding the break-even point where the NPV (net present value) of the integrated project will be equal to 0 (taking into account the revenue of the subprojects included in the complex). The practical implementation of methodological approaches to assessing the discount rate for integrated projects is relevant due to the execution of large, systemically important and integrated projects. As a result of the study, the authors put forward a methodological algorithm for determining the discount rate of an integrated project which assumes an assessment of cash flows for the subprojects included in the complex; determination of the target rate of return for subprojects; and calculation of prices for products at which a complex project become break-even. The practical implementation of methodological approaches to assessing the discount rate for integrated projects is relevant due to the execution of large systemically important integrated projects.
\end{abstract}

Keywords: economic efficiency of the project; discount rate; internal rate of return; oil and gas industry

\section{Introduction}

Investment projects' effectiveness is evaluated based on two sets of indicators, namely simple and dynamic indicators.

Simple indicators are commonly used for evaluation, but unlike dynamic indicators they do not take into account the change in the value of money over time.

Dynamic indicators (discounted payback period, net present value) are characterized by reducing the value of future flows to the current time period, for which the determination of the discount rate is of key importance. The basic approach to effectiveness assessment is based on the determining the discounted net cash flow. It consists in discounting all future cash flows (both in- and out-flow) resulting from the project with a given discount rate and then summing them together $[1,2]$. 
The main principle of the NPV approach is that the value of money tomorrow is less valuable than the value of money today. Hence, future cash flows are discounted each year. The discount rate reflects the opportunity cost of the capital mobilized, which in-creases with the estimated riskiness of the innovation opportunity. Indeed, riskier pro-jects are expected to provide higher returns. This means that such an approach is risk-adjusted, while other metrics such as ROI or IRR are not [3].

Discounting is necessary considering the diminishing value of money and is especially important for the oil and gas industry, where enterprises have a long investment cycle and the time horizon for projects reaches 20-30 years. The importance of accurate determination of the discount rate over long planning horizons is confirmed in academic works [4-6]. The article discusses the impact of information-based decisions made by managers on the strategic value of megaprojects in the oil and gas industry [7].

The discount rate indicates the rate of return for an investor when investing in a project and depends on many factors, such as the investor's expectations of return, inflationary processes, specific risks of the object in question, macroeconomic conditions, etc.

The methods for estimating the discount rate are chosen depending on the characteristics of the investment object, the enterprises having a concern in business, the financing scheme, conditions, etc. The most known methods for determining a discount rate are:

- Models of CAPM, Fama and French [8-12], and Carhartt;

- Gordon model;

- WACC model (weighted average cost of capital);

- $\quad$ Model ROA, ROE, ROCE, ROACE;

- P/E method;

- Method for evaluating risk premiums;

- Assessment method based on expert opinions [13].

Approaches to determining the discount rate have thoroughly been studied, including for investment and financial analysis in the oil and gas industry.

In article [14], the authors state that the discount rate is always linked to the availability of alternative investment options in the market. The paper focuses on the estimation of the discount rate for the enterprises of the mineral resource complex and highlights the capital asset pricing model (CAPM) as the most accurate model which is based on statistical market data and reflects both the minimum rate of return and the average market yield. Another advantage of the CAPM model is that it takes into account industry-specific risks.

The academic papers $[15,16]$ compare discount rate calculations carried out by different methods for the largest foreign and Russian companies operating in the oil and gas industry (Exxon Mobil, Chevron, Statoil, Shell, Petrochina, CNPC, GazpromNeft, Rosneft). The conclusion of the paper [15] identifies the need to apply a comprehensive approach to assessing the discount rate based on the cumulative method with an assessment of the risk component by three parameters: market risk, company risk, and specific project risk. The authors analyze the results, advantages, and disadvantages of the cumulative method, and both CAMP and WACC methods. Among the drawbacks of the CAPM method, the authors note a strong dependence on the value of the market factor $\beta$, which characterizes the behavior of shares in the securities market. The calculation data based on the WACC method are determined by the structure of the company's capital and, accordingly, depend on the cost of equity and borrowed capital $[17,18]$. Cost of equity is estimated using the capital asset pricing model (CAPM), and the cost of debt is estimated using the cost of interest from the income statements of individual firms. The weighted average cost of capital is used as a proxy for the discount rate.

The research presented in [19] also shows that for companies in the oil and gas industry, discount rates calculated by the WACC method may be overestimated due to inflated equity values derived from the CAMP model. According to the authors, the main problem is that the historical estimate $\beta$ does not provide an adequate approximation for macroeconomic risks. The authors propose to use stochastic discount rates for a given average cash flow 
growth rate. The authors on the case of BP demonstrate that the WACC discount rate is $7.6 \%$ higher than the expected stochastic discount rate.

However, a survey of companies mentioned in [2] confirms that companies mostly apply WACC method computed using the CAPM to estimate their cost of equity. Despite the prevalence of these methods, in practice companies rely on discount rates higher than the weighted average cost of capital in order to take into account additional risks [20]. According to study [21] with an average weighted capital cost of $8 \%$, the discount rate used in the investment analysis is on average $15 \%$. There are several reasons for applying the higher discount rate:

(1) Conscious rationing of capital when choosing investment projects with positive NPV due to the restrictions (for example, financial, managerial, organizational, temporary) [22,23];

(2) The need to take into account specific risks [24].

As a disadvantage of the cumulative method, the articles refer to the need for expert judgement, which reduces its objectivity. At the same time, the cumulative method has a significant advantage, namely the ability to assess the specific risks of the oil and gas industry (for example, geological). The papers $[25,26]$ focus on methods of expert risk assessment in the oil and gas industry. In so doing, article [27], notes the introduction of a risk adjustment in the discount rate as one of the popular methods of risk assessment, which confirms the relevance of the accurate valuation of the discount rate in the oil and gas industry. Unreasonable overstating the discount rate, according to the authors, may lead to the refusal to implement projects related to environmental protection measures or of social significance, as well as projects with a long settlement period. Similar issues of accurate determining the discount rate for projects that address environmental problems or introduce energy-efficient technologies are raised in [28,29]. The current problems of determining the discount rate in extreme situations such as a pandemic or global wars are discussed in study [30]; it also investigates the choice of the discount rate in the situation of climate change and environmental problems [31-35]. The evaluation of the discount rate for innovation projects is addressed in work [36].

Although the approaches to determining the discount rate have been much studied, none of the above-mentioned activities take into account the current stage of development of oil and gas companies. Book [37] rightly notes the impact of future fossil fuels on design management approaches in the oil and gas industry. Large oil and gas companies are adapting to new realities, where a low-carbon future and technological development are combined with the complexities of developing new fields $[38,39]$. The traditional oil and gas companies are gradually becoming multifunctional enterprises, dealing with both oil and gas production, transport projects, with petrochemicals, gas processing, and electricity.

For example, PJSC NK «Lukoil» is developing the Kandym Group of gas fields in Uzbekistan. The project includes not only the development of hydrocarbon resources, but also the construction of a gas processing plant having a capacity of 8 billion cubic meters of gas per year intended for the purification of hydrogen sulphide gas, the pro-duction of marketable gas, stable gas condensate and marketable sulfur.

The comprehensive approach underlies the business model of PJSC «Novatek»: the development of deposits is accompanied with creating capacities for liquefaction and gas processing, as well as the construction of its own condensate pipelines.

The investment program of PJSC «Gazprom» is also notable for many integrated projects. As an example, one can mention mega project «Yamal», which includes Bovanenkovo, Kharasaveyskoye fields, and transport capacities: "Bovanenkovo-Ukhta" and "Bovanenkovo-Ukhta-2" and the "Obskaya-Bovanenkovo" railway.

The need for a comprehensive approach to assessing the effectiveness of projects in the oil and gas industry is considered in [40], but this approach requires improvement of the methods for determining the necessary profitability of the project, taking into account the complexity, that is, the accurate assessment of the discount rate. 
It should also be noted that there is a research gap in the academic literature concerning the peculiarities of the Russian oil and gas sector development and the implementation of investment projects in the Russian Federation at the current stage:

(1) The remoteness of the producing fields from the existing unified gas supply system, which requires the simultaneous establishment of transport corridors. Despite the fact that the largest gas transportation system is available in Russia, it is often not possible to use it for new mining projects due to the remoteness of territories, which entails the construction and operation of new pipelines.

(2) Both of the projects in the extracting operations and the associated transport projects are equally capital-intensive and require appropriate attention.

(3) For extracting and transport projects, different corporate rates of return and, accordingly, discount rates are applied, therefore, for an integrated project that combines different types of activities, it is necessary to set its own discount rate.

The aim of this paper is to examine specific approaches to determining the discount rate for comprehensive computation of investment projects effectiveness in the oil and gas industry.

Section 2 has two parts. Section 2.1 provides the main and broad definitions being used for the analysis (the concept of the complexity of investment projects is considered), and Section 2.2 presents the specifics of evaluating investment projects in the oil and gas industry (capital and operating costs, tax environment, investment prices and tariffs). The first paragraphs in Section 3 provide the main result. Section 3.1 presents results related to gas transportation projects. The specificity of the discount rate evaluation for innovation projects is addressed in paper [3]. Section 3.3 presents the results obtained for the integrated project.

\section{Materials and Methods}

\subsection{The Concept of Complexity in the Oil and Gas Industry}

Before considering the characteristics of the discount rate evaluation for integrated projects, it is necessary to determine what an integrated project in the oil and gas industry is.

The main Russian regulatory document on the evaluation of the cost-effectiveness of projects [41] examines the relationship between different projects and includes concepts such as independent, mutually exclusive, complementary and mutually influencing projects. Mutually complementary cases include the construction of necessary facilities for a gas field, the construction of a gas pipeline, the implementation of an underground gas storage project and the development of a gas distribution network. The relevance of the approach lies in the fact that the evaluation results for a separate off-campus project may not satisfy the requirements of corporate profitability. Paper [40] discusses complex projects in more detail.

A complex project can be thought of as an investment project, which consists of interrelated projects for which cost-effectiveness assessments must be carried out simultaneously. The topicality of the approach lies in the fact that the evaluation results for a separate project outside the complex may not meet the requirements of corporate profitability. However, the revenues of an integrated project, which must be calculated on the basis of the current prices of the transactions, excluding accounting the internal prices and tariffs of the company, may meet all the necessary criteria.

Thus, the advisability of including a project in a company's investment program should be analyzed in terms of the relationship of the project in question to others. The financing of integrated projects also needs to be oriented towards the implementation of operations and the dynamics of industrial capacities commissioning for other projects of the complex, which will make it possible to take the right investment decisions in a rapidly changing economic and political environment, as well as to adjust development priorities. 


\subsection{Methodological Framework for Determining the Effectiveness of Integrated Investment} Projects in the Oil and Gas Sector

According to the current evaluation principles, the project includes only the revenues and expenses generated in the course of its implementation. For each investment project, capital investment and operating costs are determined according to the type of its activity: extraction, transportation, underground storage, processing, LNG production, and electricity generation. The revenue is determined based on the type of an in-vestment project, taking into account the specified value of the internal rate of return (IRR).

To assess the economic effectiveness of a mining project, capital investments (CI), operating cost $(\mathrm{OC})$ related to natural gas production, and MET are defined. The revenue is determined by reference to the product of gas extraction volume by its sale price. If a project proves to be cost-inefficient, one possible methodological approach is to determine its sale price on the basis of the estimated capital and operating costs and a given corporate rate of return for production projects.

The effectiveness of natural gas transportation projects is assessed in a similar way. To assess the economic efficiency of a transport project, the CI and OC associated with the activity are defined. The volumes of natural gas transported are accounted for on the basis of the volumes generated by the interrelated production project. Proceeds are defined as the product of a tariff on gas transportation and commodity transport, which is determined on the basis of the volume of natural gas (excluding gas for its own use) and the length of the route. If the project is not effective, it is possible to calculate a surcharge to the tariff which, at the given $\mathrm{CI}$ and OC, can lead to the corporate rate of return determined for natural gas transport projects (investment tariff).

Accordingly, the resulting metrics of economic effectiveness (net income, net discounted income, undiscounted and discounted payback periods) do not reflect the economic performance of projects at current hydrocarbon prices. However, they demonstrate the necessary sales price or tariff to achieve corporate rates of return (that is, the breakeven point for a hydrocarbon project or transportation).

The described methodological approaches used to assess the cost-effectiveness of oil and gas projects form the basis for determining the discount rate for a complex project.

The system of equations for the given example is deduced by the authors themselves.

\section{Results}

3.1. Natural Gas Production Project and Modification of the MET Calculation for Specific Cases

Consider a natural gas project whose cash flow is defined by the following parameters:

$K_{p}(t)$-the amount of capital costs per year $t$;

$E_{p}(t)$ - the amount of operating costs, including depreciation payments, per year $t$;

$N_{p}(t)$-the amount of tax payments, per year $t$;

$A_{p}(t)$-the amount of depreciation payments, per year $t$;

$V_{p}(t)$-volume of gas production, per year $t$;

$r_{p}=15 \%$ - target IRR rate for a mining project.

Let $T$ denote the tariff rate for natural gas production. Then the present cash flow of the project at the discount rate $r$ is calculated according to the formula:

$$
N P V_{p}(T, r)=\sum_{t} \frac{T \cdot V_{p}(t)-K_{p}(t)-E_{p}(t)-N_{p}(t)+A_{p}(t)}{(1+r)^{t}} .
$$

Tax payments can be divided into profit tax, MET and property tax:

$$
N_{p}(t)=N_{p, p r o f i t}(t)+N_{M E T}(t)+N_{p, p r o p e r t y}(t) .
$$


Profit tax is calculated by the formula:

$$
\begin{gathered}
N_{p, p r o f i t}(t)= \\
\begin{cases}\operatorname{Tax}_{\text {profit }} \cdot\left(T \cdot V_{p}(t)-K_{p}(t)-E_{p}(t)\right), & \text { if } T \cdot V_{p}(t)-K_{p}(t)-E_{p}(t)>0, \\
0, & \text { if } T \cdot V_{p}(t)-K_{p}(t)-E_{p}(t) \leq 0,\end{cases}
\end{gathered}
$$

where Tax $x_{\text {profit }}$-profit tax rate.

We will assume that during the fixed assets construction phase the cash flow is negative and the profit tax is zero. Next, we will look at the tariffs and gas prices that ensure the project is break-even. Under these conditions, we will assume that the cash flow $T \cdot V_{p}(t)-K_{p}(t)-E_{p}(t)$ бwill be non-negative throughout the operating period $t \geq t_{0}$, where $t_{0}$ - the year of operation commencement. Under such assumptions, the profit tax would be determined by the formula:

$$
N_{p, p r o f i t}(t)=\left\{\begin{array}{cc}
\operatorname{Tax}_{\text {profit }} \cdot\left(T \cdot V_{p}(t)-K_{p}(t)-E_{p}(t)\right), & t \geq t_{o}, \\
0, & t<t_{0} .
\end{array}\right.
$$

The formula for MET calculation is as follows:

$$
N_{M E T}(t)=\operatorname{Tax}_{M E T}(t) \cdot V_{p}(t),
$$

where the tax rate $\operatorname{Tax}_{M E T}(t)$, in its turn, is expressed by the formula

$$
\operatorname{Tax}_{M E T}(t)=35 \cdot E_{s f} \cdot K_{c}(t),
$$

which includes the price of a unit of standard fuel $E_{s f}$ and the coefficient of production complexity $K_{c}(t)$. The standard fuel price is calculated as the product of the gas price by the normative factor $\lambda$ :

$$
E_{s f}=\lambda \cdot T,
$$

and the complexity factor is calculated by the formula

$$
K_{c}(t)=\min \left(K_{d g}(t), K_{l}(t)\right) .
$$

The depletion factor of gas reserves $K_{d g}(t)$ is

$$
K_{d g}(t)= \begin{cases}1, & C_{d g}(t) \leq 0.7 \\ 2.75-2.5 \cdot C_{d g}(t), & 0.7<C_{d g}(t)<0.9 \\ 0.5, & C_{d g}(t) \geq 0.9\end{cases}
$$

where $C_{d g}(t)$-is the degree of depletion of gas reserves at the moment $t$.

The coefficient of the geographic location of the production site $K_{1}(t)$ is given by the formula

$$
K_{l}(t)= \begin{cases}0, & t-t^{*} \leq 14 \\ \frac{t-t^{*}}{10}-1.4, & 14<t-t^{*} \leq 24 \\ 1, & t-t^{*}>24\end{cases}
$$

where $t^{*}$-is the year of production in which the degree of depletion of reserves for the first time exceeds $1 \%$.

Thus, we get $N_{M E T}(t)=35 \lambda K_{c}(t) \cdot T \cdot V_{p}(t)$. 
The cited cash flow of the project can be written as:

$$
\begin{aligned}
& N P V_{p}(T, r)=\sum_{t} \frac{T \cdot V_{p}(t)-K_{p}(t)-E_{p}(t)+A_{p}(t)-N_{p, p r o f i t}(t)-N_{M E T}(t)-N_{p, p r o p e r t y}(t)}{(1+r)^{t}} \\
& =\sum_{t} \frac{T \cdot V_{p}(t)-K_{p}(t)-E_{p}(t)+A_{p}(t)-35 \lambda K_{c}(t) \cdot T \cdot V_{p}(t)-N_{p . p r o p e r t y}(t)}{(1+r)^{t}} \\
& - \text { Tax }_{\text {profit }} \sum_{t \geq t_{o}} \frac{T \cdot V_{p}(t)-K_{p}(t)-E_{p}(t)}{(1+r)^{t}} \\
& =T \cdot\left[\sum_{t} \frac{V_{p}(t)}{(1+r)^{t}}-\sum_{t} \frac{35 \lambda K_{c}(t) \cdot V_{p}(t)}{(1+r)^{t}}-\text { Tax profit } \sum_{t \geq t_{o}} \frac{V_{p}(t)}{(1+r)^{t}}\right] \\
& -\sum_{t} \frac{K_{p}(t)+E_{p}(t)+N_{p, p r o p e r t y}(t)-A_{p}(t)}{(1+r)^{t}}+\text { Tax profit } \sum_{t \geq t_{0}} \frac{K_{p}(t)+E_{p}(t)}{(1+r)^{t}}
\end{aligned}
$$

Note that $\sum_{t \geq t_{o}} \frac{V_{p}(t)}{(1+r)^{t}}=\sum_{t} \frac{V_{p}(t)}{(1+r)^{t}}$, since we assume that gas is produced for sale only during the period of operation.

The basic rate of the investment tariff for the production of natural gas $T_{p}$ o is determined by the target level of the internal rate of return $r_{p}$, which leads to equality

$$
N P V_{p}\left(T_{p}, r_{p}\right)=0
$$

whence

$$
T_{p}=\frac{\widetilde{K}_{p}\left(r_{p}\right)+\widetilde{E}_{p}\left(r_{p}\right)+\widetilde{N}_{p, \text { property }}(t)-\widetilde{A}_{p}\left(r_{p}\right)-\operatorname{Tax}_{p r o f i t}\left(\widetilde{K}_{p}^{o}\left(r_{p}\right)+\widetilde{E}_{p}^{o}\left(r_{p}\right)\right)}{\left(1-\operatorname{Tax}_{p r o f i t}\right) \cdot \widetilde{V}_{p}\left(r_{p}\right)-35 \lambda \cdot \widetilde{V}_{p}^{c}\left(r_{p}\right)}
$$

where

$\widetilde{K}_{p}(r)=\sum_{t} \frac{K_{p}(t)}{(1+r)^{t}}$-the total present capital costs of the production project;

$\widetilde{E}_{p}(r)=\sum_{t} \frac{E_{p}(t)}{(1+r)^{t}}$ - the total present operating costs for the production project;

$\widetilde{N}_{p, \text { property }}(r)=\sum_{t} \frac{N_{\text {property }}(t)}{(1+r)^{t}}$ - the total present property tax payments for the production project;

$\widetilde{A}_{p}(r)=\sum_{t} \frac{A_{p}(t)}{(1+r)^{t}}$ - the total present depreciation payments for the production project;

$\widetilde{V}_{p}(r)=\sum_{t} \frac{V_{p}(t)}{(1+r)^{t}}$-the total present volume of production;

$\widetilde{K}_{p}^{o}(r)=\sum_{t \geq t_{o}} \frac{K_{p}(t)}{(1+r)^{t}}$-the present capital costs of the production project for the period of operation;

$\widetilde{E}_{p}^{o}(r)=\sum_{t \geq t_{o}} \frac{E_{p}(t)}{(1+r)^{t}}$-the total present operating costs of the production project for the period of operation;

$\widetilde{V}_{p}^{c}(r)=\sum_{t} \frac{K_{c}(t) \cdot V_{p}(t)}{(1+r)^{t}}$ - the total present volume of production by taking into account the complexity.

\subsection{Natural Gas Transportation Project}

The cash flow of a natural gas transport project is set by similar parameters:

$K_{t r}(t)$-the amount of capital costs per year $t$;

$E_{t r}(t)$ - the amount of operating costs per year $t$;

$N_{t r}(t)$ - the amount of operating costs per year $t$;

$A_{t r}(t)$ - the amount of depreciation payments, per year $t$;

$V_{t r}(t)$-volume of natural gas transported, per year $t$;

$r_{t r}=12 \%$-target IRR rate for a transportation project. 
The project cash flow with the transportation tariff rate $T$ and the discount rate $r$ is calculated using the formula

$$
N P V_{t r}(T, r)=\sum_{t} \frac{T \cdot V_{t r}(t)-K_{t r}(t)-E_{t r}(t)-N_{t r}(t)+A_{t r}(t)}{(1+r)^{t}}
$$

the amount of property $N_{t r, p r o p e r t y}(t)$ and profit taxes $N_{t r, p r o f i t}(t)$, taken as tax payments that are calculated by the formula

$$
N_{t r, p r o f i t}(t)=\left\{\begin{array}{cc}
\operatorname{Tax}_{p r o f i t} \cdot\left(T \cdot V_{t r}(t)-K_{t r}(t)-E_{t r}(t)\right), & \text { если } T \cdot V_{t r}(t)-K_{t r}(t)-E_{t r}(t)>0, \\
0, & \text { если } T \cdot V_{t r}(t)-K_{t r}(t)-E_{t r}(t) \leq 0 .
\end{array}\right.
$$

As in the case of a production project, we assume that the cash flow of the project is negative during the fixed assets construction phase and, when the project is break-even, it remains positive during the whole operational period. Under these assumptions, to calculate the tax we can apply the formula

$$
N_{t r, p r o f i t}(t)=\left\{\begin{array}{cc}
\operatorname{Tax}_{\text {profit }} \cdot\left(T \cdot V_{t r}(t)-K_{t r}(t)-E_{t r}(t)\right), & t \geq t_{0} \\
0, & t<t_{0}
\end{array}\right.
$$

The basic rate of the investment tariff for natural gas transportation $T_{t r}$ is determined by the target level of the internal rate of return $r_{t r}$, which leads to

$$
N P V_{t r}\left(T_{t r}, r_{t r}\right)=0
$$

and

$$
T_{t r}=\frac{\widetilde{K}_{t r}\left(r_{t r}\right)+\widetilde{E}_{t r}\left(r_{t r}\right)+N_{t r, p r o p e r t y}(t)-\widetilde{A}_{t r}\left(r_{t r}\right)-\operatorname{Tax}_{\text {profit }}\left(\widetilde{K}_{t r}^{o}\left(r_{t r}\right)+\widetilde{E}_{t r}^{o}\left(r_{t r}\right)\right)}{\left(1-\operatorname{Tax}_{\text {profit }}\right) \cdot \widetilde{V}_{t r}\left(r_{t r}\right)},
$$

where

$\widetilde{K}_{t r}(r)=\sum_{t} \frac{K_{t r}(t)}{(1+r)^{t}}$ - the total present capital costs of the transportation project,

$\widetilde{E}_{t r}(r)=\sum_{t} \frac{E_{t r}(t)}{(1+r)^{t}}$ - the total present operating costs of the transportation project,

$\widetilde{N}_{t r, \text { property }}(r)=\sum_{t} \frac{N_{t r}, \text { property }(t)}{(1+r)^{t}}$ 一 the total present property tax payments for the transportation project;

$\widetilde{A}_{t r}(r)=\sum_{t} \frac{A_{t r}(t)}{(1+r)^{t}}$ - the total present depreciation payments for the transportation project; $\widetilde{V}_{t r}(r)=\sum_{t} \frac{V_{t r}(t)}{(1+r)^{t}}$ - the total present volume of natural gas transported;

$\widetilde{K}_{t r}^{o}(r)=\sum_{t \geq t_{o}} \frac{K_{t r}(t)}{(1+r)^{t}}$-the present capital costs of the transportation project for the period of operation;

$\widetilde{E}_{t r}^{o}(r)=\sum_{t \geq t_{o}} \frac{E_{t r}(t)}{(1+r)^{t}}$-the present operating costs of the transportation project for the period of operation.

\subsection{Determining the Discount Rate for a Complex Project}

Now $\mathrm{P}$ is the market price of natural gas. Assume that the volumes of production and transportation in each year $t$ are the same: $V_{p}(t)=V_{t r}(t)=V(t)$, that is, all the gas produced is transported. Let us assess the cost-effectiveness of the three projects:

Natural gas production project, including its transportation costs. The cash flow of the project consists of revenues from natural gas sales $P \cdot V(t)$, capital expenditures $K_{p}(t)$, operating expenses $E_{p}(t)$, tax payments $N_{p}(t)$, depreciation payments $A_{p}(t)$ and 
transportation costs of natural gas $T_{t r} \cdot V(t)$. The net present costs of the project is thus calculated by the formula

$$
N P V^{\prime}{ }_{p}(P)=\sum_{t} \frac{P \cdot V(t)-K_{p}(t)-E_{p}(t)-N_{p}(t)+A_{p}(t)-T_{t r} \cdot V(t)}{\left(1+r_{p}\right)^{t}} .
$$

Natural gas transportation project, including its production costs. The cash flow of the project consists of revenues from natural gas sales $P \cdot V(t)$, capital expenditures $K_{\mathrm{tr}}(t)$, operating expenses $E_{\operatorname{tr}}(t)$, tax payments $N_{\operatorname{tr}}(t)$, depreciation payments $A_{\operatorname{tr}}(t)$ and production costs of natural gas $T_{\mathrm{p}} \cdot V(t)$. The net present costs of the project is thus calculated by the formula

$$
N P V^{\prime}{ }_{t r}(P)=\sum_{t} \frac{P \cdot V(t)-K_{t r}(t)-E_{t r}(t)-N_{t r}(t)+A_{t r}(t)-T_{p} \cdot V(t)}{\left(1+r_{t r}\right)^{t}} .
$$

Complex project of natural gas transportation. The cash flow of the project consists of revenues from natural gas sales $P \cdot V(t)$, total capital expenditures $K_{p}(t)+K_{t r}(t)$, operating expenses $E_{p}(t)+E_{t r}(t)$, tax payments $N_{p}(t)+N_{t r}(t)$ and depreciation payments $A_{p}(t)+$ $A_{t r}(t)$. The net present revenue of the project with the discount rate $r$ is

$$
N P V(P, r)=\sum_{t} \frac{\begin{array}{c}
P \cdot V(t)-\left(K_{p}(t)+K_{t r}(t)\right)-\left(E_{p}(t)+E_{t r}(t)\right)- \\
\left(N_{p}(t)+N_{t r}(t)\right)+\left(A_{p}(t)+A_{t r}(t)\right)
\end{array}}{(1+r)^{t}} .
$$

Let us calculate the price for natural gas at which the projects is break-even.

For a natural gas project with transportation costs, the break-even requirement is as follows $N P V^{\prime}{ }_{p}\left(P_{p}^{*}\right)=0$. We will write this requirement in more detail

$$
\begin{aligned}
N P V_{p}\left(P_{p}^{*}, r\right) & =\sum_{t} \frac{P_{p}^{*} \cdot V(t)-K_{p}(t)-E_{p}(t)-T_{t r} \cdot V(t)+A_{p}(t)-N_{p, p r o f i t}(t)-N_{M E T}(t)-N_{p, p r o p e r t y}(t)}{(1+r)^{t}} \\
& =\sum_{t} \frac{P_{p}^{*} \cdot V(t)-K_{p}(t)-E_{p}(t)-N_{p, p r o p e r t y}(t)-T_{t r} \cdot V(t)+A_{p}(t)-35 \lambda K_{c}(t) \cdot P_{p}^{*} \cdot V(t)}{(1+r)^{t}} \\
& -\operatorname{Tax}_{\text {profit }} \sum_{t \geq t_{e}} \frac{P_{p}^{*} \cdot V(t)-K_{p}(t)-E_{p}(t)-T_{t r} \cdot V(t)}{(1+r)^{t}} \\
& =P_{p}^{*} \cdot\left(\widetilde{V}\left(r_{p}\right)-35 \lambda \cdot \widetilde{V}^{c}\left(r_{p}\right)-\operatorname{Tax}_{\text {profit }} \cdot \widetilde{V}\left(r_{p}\right)\right) \\
& -\left(\widetilde{K}_{p}\left(r_{p}\right)+\widetilde{E}_{p}\left(r_{p}\right)+T_{t r} \cdot \widetilde{V}\left(r_{p}\right)+N_{p, \text { property }}(t)-\widetilde{A}_{p}\left(r_{p}\right)\right) \\
& + \text { Tax profit }\left(\widetilde{K}_{p}^{o}\left(r_{p}\right)+\widetilde{E}_{p}^{o}\left(r_{p}\right)+T_{t r} \cdot \widetilde{V}\left(r_{p}\right)\right)=0,
\end{aligned}
$$

whence

$$
\begin{gathered}
P_{p}^{*}=\frac{\widetilde{K}_{p}\left(r_{p}\right)+\widetilde{E}_{p}\left(r_{p}\right)+T_{t r} \cdot \widetilde{V}\left(r_{p}\right)+\widetilde{N}_{p, p r o p e r t y}(t)-\widetilde{A}_{p}\left(r_{p}\right)-\operatorname{Tax}_{p r o f i t}\left(\widetilde{K}_{p}^{o}\left(r_{p}\right)+\widetilde{E}_{p}^{o}\left(r_{p}\right)+T_{t r} \cdot \widetilde{V}\left(r_{p}\right)\right)}{\left(1-\operatorname{Tax}_{\text {profit }}\right) \cdot V_{p}\left(r_{p}\right)-35 \lambda \cdot \widetilde{V}_{p}^{c}\left(r_{p}\right)} \\
=T_{p}+T_{t r} \cdot\left(1+\frac{35 \lambda \cdot \widetilde{V}_{p}^{c}\left(r_{p}\right)}{\left(1-\operatorname{Tax}_{p r o f i t}\right) \cdot \widetilde{V}_{p}\left(r_{p}\right)-35 \lambda \cdot \widetilde{V}_{p}^{c}\left(r_{p}\right)}\right) .
\end{gathered}
$$

For a natural gas transportation project taking into consideration the production, the break-even requirement is as follows $N P V_{t p}^{\prime}\left(P_{t p}^{*}\right)=0$. Thus,

$N P V^{\prime}{ }_{t r}\left(P_{t r}^{*}\right)=P_{t r}^{*} \cdot\left(1-\operatorname{Tax}_{\text {profit }}\right) \cdot \widetilde{V}_{t r}\left(r_{t r}\right)-\left[\widetilde{K}_{t r}\left(r_{t r}\right)+\widetilde{E}_{t r}\left(r_{t r}\right)+T_{p} \cdot \widetilde{V}\left(r_{t r}\right) \widetilde{+N}_{t r, p r o p e r t y}(t)-\widetilde{A}_{t r}\left(r_{t r}\right)-\operatorname{Tax} x_{\text {profit }}\left(\widetilde{K}_{t r}^{o}\left(r_{t r}\right)+\widetilde{E}_{t r}^{o}\left(r_{t r}\right)+T_{p} \cdot \widetilde{V}\left(r_{t r}\right)\right)\right]=0$ 
whence

$$
\begin{aligned}
& P_{t r}^{*} \\
& =\frac{\widetilde{K}_{t r}\left(r_{t r}\right)+\widetilde{E}_{t r}\left(r_{t r}\right)+T_{p} \cdot \widetilde{V}\left(r_{t r}\right)+\widetilde{N}_{t r, p r o p e r t y}(t)-\widetilde{A}_{t r}\left(r_{t r}\right)-T a x_{\text {profit }}\left(\widetilde{K}_{t r}^{o}\left(r_{t r}\right)+\widetilde{E}_{t r}^{o}\left(r_{t r}\right)+T_{p} \cdot \widetilde{V}\left(r_{t r}\right)\right)}{\left(1-T a x_{\text {profit }}\right) \cdot \widetilde{V}_{t r}\left(r_{t r}\right)} \\
& =T_{p}+T_{t r} .
\end{aligned}
$$

Thus, the prices for natural gas, for which extraction and transportation projects are to be break-even, are slightly different: $P_{p}^{*}>P_{t r}^{*}=T_{p}+T_{t r}$. Thus, the prices for natural gas, for which extraction and transportation projects are to be break-even, are slightly different.

The question is: will the total tariff be a break-even point for a complex project? Since the NPV of the project $N P V(P, r)$ depends on the discount rate, the question posed can be reformulated as follows: at what discount rate $r^{*}$ does equality take place $N P V\left(T_{p}+T_{t r}, r^{*}\right)=0 ?$

Thus $r^{*}$, which is the solution to the equation $N P V\left(T_{p}+T_{t r}, r^{*}\right)=0$, is the target rate for a complex project.

\section{Discussion}

Determining the discount rate for assessing the effectiveness of investment projects raises several debatable problems at once, requiring further detailed consideration.

The limitations of the approach presented by the authors are explained by considering the discount rate to the financial context from the investor's point of view. Properly determined discount rate is important for the investors to make them keener to put the money in the project. The proposed approach to determining the discount rate is more related to the social time preference approach, which assumes that one should keep investing in available projects as long as the rate of return is above the discount rate. But nowadays investors are not the only ones who are involved in the investment process. Therefore a more comprehensive discount rate is needed to consider the project's impact on different stakeholders; they are not the only party to the economy. The government has become a full valid player in the investment process, which is particularly important for the major systemically important industries, such as the oil and gas sector for Russia. In addition, strategic investment projects are often linked to national security strategy priorities. Hence, the social opportunity cost of capital discount rate might be a more appropriate discount rate when evaluating government projects. The social discount rate plays a pivotal role in economic evaluation of any investment or policy that has long-term consequences. This rate should reflect both the cost of anticipating and the cost of taking non-diversifiable investment risk [42].

Social discount rate, which makes it possible to compare the social benefits and costs extended over a period of time, has a key role in the allocation of public resources among alternative ends via cost-benefit analysis. The public sector needs to use the correct social discount rate in order to achieve a fair allocation of the fiscal burden between generations. While a high social discount rate may place a heavy fiscal burden on future generations, a low social discount rate may cause unfeasible projects to be approved [43].

The use of a social discount rate is of particular importance for public sector projects and involves the determination of the welfare gains expressed in monetary terms and costs, as well as their correlation over time with budget expenditures. However, the public benefits of a project are often intangible and difficult to measure in monetary terms. In addition, the bulk of the investment is made at the start of the project, while the social effects take a long time to materialize.

This approach, associated with the social discount rate, is especially important for projects implemented in industries with a high share of government participation, where operation of market mechanisms is restricted. Thus, additional research is required to assess the social discount rate for projects in the oil and gas industry in Russia.

Another important issue requiring further examination is the issue of determining the discount rate for real or nominal cash flows is of particular importance. 
The importance and relevance of the problem of accounting for inflationary effects in investment calculations is evidenced by the regular addressing this problem by the authors of dissertations and the practitioners' attention [44] Academic researchers have found empirical evidence that inflation is negatively correlated with stock market returns $[45,46]$. Investors often underestimate the impact of inflation, which leads to an increase in the cost of capital in real terms and a decrease in the market value of shares [47]. Inflation can affect both the current financial performance and the value of anticipated future cash flows [48].

While for developed countries the issue of evaluating investment projects with or without inflation is hardly urgent, for projects in emerging markets the issue is topical and needs further study. Investment projects in developed markets are generally estimated on the basis of inflation, as inflationary processes are fairly stable and their forecasting is not difficult. For emerging markets, determining the accurate inflation projection for cash flows, including the discount rate, is a challenge.

\section{Conclusions}

In line with the research gap highlighted in the introduction, the authors have attempted to find a solution to determining the discount rate for complex investment projects in the oil and gas industry, taking into account: the equivalent capital intensity of projects in the complex (for example, with two types of activities: extraction and transport); the critical importance of correct and accurate determination of the discount rate for complex projects, since the period of the projects implementation in the oil and gas industry and their capital intensity leads to the fact to: that every additional percentage that increases the discount rate may lead to inflated expectations for returns on the project and eventually to the possibility of a wrong decision not to proceed with the project.

The limitations on the approach proposed by the authors to determining the discount rate are related to the possibility of applying the developed system of equations to capitalintensive complex projects in the Russian oil and gas industry. Application to complex projects involving other activities (e.g., LNG, gas processing) or being undertaken in other countries may require additional research.

The practical implementation of methodological approaches to assessing the discount rate for integrated projects is relevant due to the execution of large systemically important integrated projects.

Methodological approaches to assessing the discount rate of a complex project involve:

(1) The assessment of cash flows for the subprojects included in the complex;

(2) The determination of the target rate of return for subprojects;

(3) The calculation of the prices for products, at which an integrated project becomes break-even.

The authors consider methodological approaches to assessing the discount rate of a complex project, where the subprojects are production and transport projects of the oil and gas industry.

According to [49], the implementation of megaprojects is associated with risks of a social, technical, economic, political and psychological nature, since it is necessary to meet the requirements of many stakeholders; monitor the excess of capital investments; and to solve the problems of inflated expectations and accuracy of forecasts. The authors consider two megaprojects in the oil and gas industry: the Nabucco project (in Europe) and the trans-ASEAN gas pipeline network (in Asia).

Proper determination of the discount rate for a complex project will minimize risks and accurately determine the value of the designed project for investors. Determining the effectiveness of a complex project requires a detailed assessment of the discount rate for all subprojects included in it. Thus, the proposed methodological approaches are aimed at increasing the reliability and validity of the outcomes of the economic assessment of integrated projects in the oil and gas industry.

The results of this study can be used in the investment analysis of complex in-vestment projects in the oil and gas industry, updating the metrics of the economic efficiency of 
projects, monitoring the implementation of complex projects, and making decisions on including projects in the company's investment program.

Areas for future research include:

1. The use of nominal and real discount rates for projects implemented in emerging markets;

2. The use of a constant or time-varying discount rate [50];

3. Determining discount rate for:

3.1 Integrated oil and gas projects comprising UGS activities, processing, LNG;

3.2 Investment projects (including complex ones) with public participation;

3.3 Investment projects without obvious commercial effect but with significant social impacts.

Author Contributions: Methodology, T.K.; project administration, A.K.; visualization, O.K.; Writingoriginal draft, Y.N.; Writing-review \& editing, N.S. All authors have read and agreed to the published version of the manuscript.

Funding: This research received no external funding.

Institutional Review Board Statement: Not applicable.

Informed Consent Statement: Not applicable.

Data Availability Statement: Not applicable.

Conflicts of Interest: The authors declare no conflict of interest.

\section{References}

1. Zizlavsky, O. Net Present Value Approach: Method for Economic Assessment of Innovation Projects. Procedia—Soc. Behav. Sci. 2014, 156, 506-512. [CrossRef]

2. Jagannathan, R.; Matsa, D.A.; Meier, I.; Tarhan, V. Why do firms use high discount rates? J. Financ. Econ. 2016, 120, 445-463. [CrossRef]

3. Gailly, B. Developing Innovative Organizations: A Roadmap to Boost Your Innovation Potential, 1st ed.; Palgrave Macmillan: Basingstoke, UK, 2011.

4. Lloyd-Smith, P.; Adamowicz, W.; Entem, A.; Fenichel, E.P.; Rouhi Rad, M. The decade after tomorrow: Estimation of dis-count rates from realistic temporal decisions over long time horizons. J. Econ. Behav. Organ. 2021, 183, 158-174. [CrossRef]

5. Arrow, K.; Cropper, M.; Gollier, C.; Groom, B.; Heal, G.; Newell, R.; Nordhaus, W.; Pindyck, R.; Pizer, W.; Portney, P.; et al. Determining Benefits and Costs for Future Generations. Science 2013, 341, 349-350. [CrossRef] [PubMed]

6. Arrow, K.J.; Cropper, M.L.; Gollier, C.; Groom, B.; Heal, G.M.; Newell, R.; Nordhaus, W.D.; Pindyck, R.S.; Pizer, W.A.; Portney, P.R.; et al. Should Governments Use a Declining Discount Rate in Project Analysis? Rev. Environ. Econ. Policy 2014, 8, 145-163. [CrossRef]

7. Eweje, J.; Turner, R.; Müller, R. Maximizing strategic value from megaprojects: The influence of information-feed on decisionmaking by the project manager. Int. J. Proj. Manag. 2012, 30, 639-651. [CrossRef]

8. Chai, D.; Chiahb, M.; Zhongc, A. Choosing factors: Australian evidence. Pac. Basing Financ. J. 2019, 58, 1-9. [CrossRef]

9. Fama, E.F.; French, K.R. Common risk factors in the returns on stocks and bonds. J. Financ. Econ. 1993, 33, 3-56. [CrossRef]

10. Fama, E.F.; French, K.R. Size, value, and momentum in international stock returns. J. Financ. Econ. 2012, 105, 457-472. [CrossRef]

11. Fama, E.F.; French, K.R. A five-factor asset pricing model. J. Financ. Econ. 2015, 116, 1-22. [CrossRef]

12. Fama, E.F.; French, K.R. Choosing factors. J. Financ. Econ. 2018, 128, 234-252. [CrossRef]

13. Zhdanov, I.Y.; Zhdanov, V.Y. Investment Valuation of Projects and Business: Tutorial; Prospekt: Moscow, Russia, 2019.

14. Podkorytov, V.N.; Mochalova, L.A. Determination of the discount rate for the conditions of enterprises of the mineral resources sector: Argumentative issues. In News of the Ural State Mining University; Ural State Mining University: Yekaterinburg, Russia, 2019; Volume 2, pp. 121-125.

15. Chadina, D.N. The rationale for choosing the discount rate when evaluating the effectiveness of investment projects in the oil and gas industry. In Proceedings of the 55th International Scientific Student Conference, Proceedings of ISSC-2017: Economics, Novosibirsk, Russia, 17-20 April 2017; Novosibirsk National Research State University: Novosibirsk, Russia, 2017 ; pp. 43-44.

16. Niyazbekova, D.B.; Komarova, A.V. Determining the discount rate for oil and gas companies. In Proceedings of the XVI International Scientific Conference, Natural Resources Management, Mining, Areas and Technologies of Prospecting, Exploration and Development of Mineral Deposits, Economy, Geoecology, Novosibirsk, Russia, 20-24 April 2020; INGG SB RAS: Novosibirsk, Russia, 2020; pp. 873-882.

17. Ateeq, R.M. The impact of investor sentiment on returns, cash flows, discount rates, and performance. Borsa Istanb. Rev. 2021, 21, $1-11$. 
18. Womack, K.; Zhang, Y. Core Finance Course Trends in the Top MBA Programs in 2005. SSRN Electronic Journal Unpublished Working Paper. Available online: https://www.researchgate.net/publication/228169073_Core_Finance_Trends_in_the_Top_ MBA_Programs_in_2005 (accessed on 14 August 2021).

19. Zhukov, P.E. New Models for Analyzing Changes in Company Value Based on Stochastic Discount Rates. Financ. Theory Pract. 2019, 23, 35-48. [CrossRef]

20. Jacobs, M.; Shivdasani, A. Do you know your cost of capital? Harv. Bus. Rev. 2012, 90, 118-124.

21. Graham, J.; Harvey, C. Duke/CFO Magazine Global Business Outlook, U.S. Topline Tables, Released 9 March 2011. Available online: https:/ / archive.org/details/podcast_dukecfo-magazine-global-busin_cfo-survey-march-2011_1000092787378 (accessed on 14 August 2021).

22. Emery, D.; Finnerty, J.; Stowe, J. Corporate Financial Management, 4th ed.; Wohl Publishing: Morristown, NJ, USA, 2011.

23. Asvanunt, A.; Broadie, M.; Sundaresan, S. Managing corporate liquidity: Strategies and pricing implications. Int. J. Theor. Appl. Financ. 2011, 14, 369-406. [CrossRef]

24. Holmström, B. The firm as a subeconomy. J. Law Econ. Organ. 1999, 15, 74-102. [CrossRef]

25. Demkin, I.V.; Nikonov, I.M.; Gabrielov, A.A.; Barkhatov, V.D.; Petrova, M.S. Methodological problems of risk analysis of oil and gas projects (part I). In Issues of Economics and Management of Oil and Gas Complex; Gubkin Publishing House: Moscow, Russia, 2016; Volume 4, pp. 18-27. (In Russian)

26. Boldyrev, E.S.; Burenina, I.V.; Zakharova, I.M. Risk inventory when evaluating investment projects in the oil and gas industry. Naukovedenie 2016, 8, 1-11.

27. Velikanova, T.V.; Kiforenko, I.K. Information component in the solution of problems of rational placement of objects processing of household waste. Fundam. Res. 2015, 2, 5428-5432.

28. Markanday, A.; Galarraga, I.; Chiabai, A.; de Murieta, E.S.; Lliso, B.; Markandya, A. Determining discount rates for the evaluation of natural assets in land-use planning: An application of the Equivalency Principle. J. Clean. Prod. 2019, 230, 672-684. [CrossRef]

29. Carrasco-Garcés, M.; Vásquez-Lavín, F.; Oliva, R.D.P.; Pincheira, F.D.; Barrientos, M. Estimating the implicit discount rate for new technology adoption of wood-burning stoves. Energy Policy 2021, 156, 112407. [CrossRef]

30. Masoliver, J.; Montero, M.; Perelló, J. Jump-Diffusion Models for Valuing the Future: Discounting under Extreme Situations. Mathematics 2021, 9, 1589. [CrossRef]

31. Stern, N. The Economics of Climate Change: The Stern Review; Cambridge University Press: Cambridge, UK, 2007.

32. Nordhaus, W. The "Stern Review" on the Economics of Climate Change. J. Econ. Lit. 2007, 45, 687-702. [CrossRef]

33. Nordhaus, W. Critical Assumptions in the Stern Review on Climate Change. Science 2007, 317, 201-202. [CrossRef] [PubMed]

34. Stern, N. Ethics, equity and the economics of climate change paper 1: Science and philosophy. Econ. Philos. 2014, 30, 397-444. [CrossRef]

35. Stern, N. Ethics, equity and the economics of climate change paper 2: Economics and politics. Econ. Philos. 2014, 30, 445-501. [CrossRef]

36. Nazarova, Y.A.; Kindrashina, A.S. Approaches to assessing the economic efficiency of innovative projects. In Vestnik RGGU. Seriâ: Ėkonomika, Upravlenie, Pravo; RGGU: Moscow, Russia, 2020; Volume 1, pp. 68-81. (In Russian)

37. Altawell, N. 5-Project management in oil and gas. In Rural Electrification; Elsevier: New York, NY, USA, 2021 ; pp. 91-107.

38. Merkulov, V.; Tkachenko, L. Problems of russian oil and gas complex in view of new geopolitical factors influence. Rsuh/Rggu Bull. 2015, 1, 61-65. (In Russian) [CrossRef]

39. Mouraviev, N. Renewable energy in Kazakhstan: Challenges to policy and governance. Energy Policy 2021, 149, 112051. [CrossRef]

40. Nazarova, Y.A.; Kropina, E.A.; Shishkin, A.G.; Gavryusev, S.V. Approaches to assessing the effectiveness of integrated in-vestment projects: Evidence from the Russian fuel and energy industry. Econ. Anal. Theory Pract. 2019, 5, 895-909. [CrossRef]

41. Kossov, V.V.; Livshits, V.N.; Shakhnazarov, A.G. Methodological Recommendations for Evaluating the Effectiveness of Investment Projects, 2nd ed.; Economics Publishing House: Moscow, Russia, 2000.

42. Hultkrantz, L. Social discount rates. In International Encyclopedia of Transportation; Elsevier: New York, NY, USA, 2021; pp. 195-200.

43. Akbulut, H.; Seçilmiş, E. Estimation of a social discount rate for Turkey. Socio-Econ. Plan. Sci. 2019, 67, 78-85. [CrossRef]

44. Koller, T.; Goedhart, M.; Wessels, D. Valuation: Measuring and Managing the Value of Companies; John Wiley \& Sons: Hoboken, NJ, USA, 2010.

45. Lewellen, W.G.; Ang, J.S. Inflation, Security values and Risk Premia. J. Financ. Res. 1982, 5, 105-123. [CrossRef]

46. Ritter, J.R.; Warr, R.S. The Decline of Inflation and the Bull Market of 1982-1999. J. Financ. Quant. Anal. 2002, 37, 29. [CrossRef]

47. Modigliani, F.; Cohn, R. Inflation, Rational Valuation, and the Market. Financ. Anal. J. 1979, 35, 24-44. [CrossRef]

48. Canada, J.R.; White, J.A. Capital Investment Decision Analysis for Engineering and Management; Prentice Hall: Hoboken, NJ, USA, 1996.

49. Graaf, T.; Sovacool, B.K. Thinking big: Politics, progress, and security in the management of Asian and European energy megaprojects. In Energy Policy; Elsevier: New York, NY, USA, 2014; pp. 16-27.

50. Lorenz, D.; Kruschwitz, L.; Löffler, A. Are costs of capital necessarily constant over time and across states of nature? Some remarks on the debate on 'WACC is not quite right'. Q. Rev. Econ. Financ. 2016, 60, 81-85. [CrossRef] 